\title{
The Effect of Prey Density on Life Table Parameters of Hippodamia variegata (Coleoptera: Coccinellidae) Fed on Aphis gossypii (Hemiptera: Aphididae) under Laboratory Conditions
}

\author{
Soodeh Davoodi Dehkordi, Ahad Sahragard, and Jalil Hajizadeh \\ Department of Plant Protection, Faculty of Agriculture, University of Guilan, P.O. Box 41635-1314, Rasht, Iran \\ Correspondence should be addressed to Ahad Sahragard; sahra1330@yahoo.com
}

Received 14 May 2013; Accepted 18 June 2013

Academic Editors: C. J. Bidau, J. Serrano, and C. Silva-Torres

Copyright (c) 2013 Soodeh Davoodi Dehkordi et al. This is an open access article distributed under the Creative Commons Attribution License, which permits unrestricted use, distribution, and reproduction in any medium, provided the original work is properly cited.

\begin{abstract}
Life table gives the most comprehensive explanation of the survivorship, development, and reproduction of a population. The life table parameters of ladybeetle, Hippodamia variegata (Coleoptera: Coccinellidae), on different densities $(20,40,60,80$, and 100) of third instar nymphs of Aphis gossypii were studied in a growth chamber $\left(25 \pm 1^{\circ} \mathrm{C}, 65 \pm 5 \% \mathrm{RH}\right.$, and a photoperiod of $16 \mathrm{~L}$ : $8 \mathrm{D} \mathrm{h}$ ). The adult preovipositional period and the total preovipositional period of female $\mathrm{H}$. variegata were reduced as the prey density increased. The oviposition period was longer when prey density increased. Female longevity also increased significantly with increasing prey density. Fecundity was dependent on prey density. The lowest fecundity was obtained at density of 20 prey $(70.7 \pm 8.3)$ and the highest at density of $100(1132.2 \pm 57.6$ eggs). Intrinsic rate of increase was dependent on prey density and ranged from $0.0788 \pm 0.005$ to $0.187 \pm 0.009 \mathrm{~d}^{-1}$ (female/female/day) with increasing prey density. Net reproductive rate and gross reproductive rate were also increased with increasing prey density. The peak reproductive values were dependent on prey density. However, mean generation time decreased as prey density increased. It was concluded that the increase in the density of $A$. gossypii nymphs had positive and significant effects on reproductive parameters of $H$. variegata.
\end{abstract}

\section{Introduction}

Aphids are a diverse group of plant feeding insects that are predominantly found in temperate climate zones such as North America, Europe, Central, and Eastern Asia [1]. They cause damage directly by sucking plant sap, secrete honeydew resulting in development of sooty mould on leaves and shoots, and indirectly as vectors of certain plant viruses $[2,3]$. The cotton aphid, Aphis gossypii Glover (Hemiptera: Aphididae) as a cosmopolitan and polyphagous species is widely distributed in tropical, subtropical and temperate regions. This aphid is a pest of cotton, cucurbits, and citrus and principally attacks vegetables in fields and greenhouses [4].

The lady beetles are the most commonly known worldwide beneficial insects [5]. The Coccinellids are of great economic importance in agroecosystems through their successful application in the biological control of many injurious insects [6]. The variegated lady beetle, Hippodamia variegata
(Goeze), is an active predator used in the biological control of aphids in cereals and oil plants in various countries [79]. This Coccinellid, as an important aphidophagous predator in Europe [10], is widely distributed in a large portion of the Palearctic region [7]. In Australia, the ladybeetle was recorded preying on 12 aphid species and one psyllid species attacking various crops, weeds, and ornamental plants [11].

Life table analysis is a standard ecological method to estimate demographic parameters related to population dynamics [12]. Estimation of vital statistics, such as intrinsic rate of increase, generation time, finite rate of increase, and doubling time, help explain oscillations in population density and provide a better understanding of the population dynamics of a species [13, 14]. Southwood [13] stated that the intrinsic rate of increase is the most useful life table parameter to compare the population growth potential of different species under specific climatic and food conditions. By correlating studies on the predation rate and life table and by considering 
variations due to age, stage, and sex into account, the growth, stage variability, reproduction, and the predation rate can be effectively characterized [15].

The life history of many insects has been studied using the traditional female age-specific life table (e.g., [16-21]). In a female age-specific life table, only female individuals are taken into account, and the variable developmental rate among individuals is ignored (e.g., [22-24]). The life table parameters of $H$. variegata have been studied using traditional female age-specific life tables of individuals reared on several species of aphids including Dysaphis crataegi (Kaltenbach), A. gossypii, Myzus persicae Sulz, Brevicoryne brassicae (L.), and Rhopalosiphum padi (L.) as prey on various crops under various environmental conditions [8, 25-28]. Chi and Liu [29] and Chi [30] developed an age-stage, twosex life table theory to take both sexes and variable developmental rates among individuals into consideration. Chi and Yang [15] applied the age-stage, two-sex life table to the predator, Proplyea japonica Thunberg (Coleoptera: Coccinellidae), and showed it can properly include the variable predation rate of different predator stages. Yu et al. [31] applied the same life table in studying the predation rate of Lemnia biplagiata (Schwartz) (Col., Coccinellidae) fed on A. gossypii. Schneider et al. [32] also used this approach to study the effect of glyphosate on the development, fertility, and demography of Chrysoperla externa (Neuroptera: Chrysopidae). This method was also used to study the life tables of the parasitoid wasp, Aphidius gifuensis (Ashmead), (Hym., Braconidae), and its host, Myzus persicae (Sulzer) (Hemiptera: Aphididae) [33].

The objectives of this study were to construct, describe, and analyze life table parameters for $H$. variegata population exposed to different densities of third instar A. gossypii. We intended to find out the effect of prey density on life table parameters such as age-stage-specific survival and fecundity, reproductive value, net reproductive value $\left(R_{0}\right)$, intrinsic rate of increase $\left(r_{m}\right)$, and finite rate of increase $(\lambda)$. These parameters can be used to estimate the rate of increase of a natural or released population [8] and to determine when to release laboratory-reared coccinellids.

\section{Materials and Methods}

2.1. Insect Culture. Adult insects of $H$. variegata were collected from an alfalfa field in the Shahrekord region, Chaharmahal, and Bakhtiari Province, Iran, in June 2010, and reared on black eye bean (Vigna unguiculata L.) infested with A. gossypii.

The A. gossypii nymphs were collected from a cucumber field in Rasht area. They were reared on potted $(20 \mathrm{~cm}$ in diameter) cucumber varieties such as Super dominus and US Agriseeds in a greenhouse (at average temperature of $25 \pm 1^{\circ} \mathrm{C}$ with the range of $18-35^{\circ} \mathrm{C}$ ) in order to have access to a steady supply of prey for experiments.

2.2. Experimental Conditions. Transparent plastic containers $(15 \times 13 \times 3 \mathrm{~cm})$ were used as experimental arena. All experiments were carried out at $25 \pm 1^{\circ} \mathrm{C}, 65 \pm 5 \%$ R.H., and a photoperiod of $16: 8(\mathrm{~L}: \mathrm{D}) \mathrm{h}$.
2.3. Life Table Study. Newly emerged 1st instar larvae of $H$. variegata were released individually in experimental arenas and offered densities of 20, 40, 60, 80, and 100 third instar A. gossypii nymphs on black eye bean fresh leaves to study their life table parameters. The duration of the successive developmental stages and the mortality was recorded. When fresh food was provided, the number of prey consumed was counted daily at each prey density to determine the total number of prey eaten (from 1st instar larva to adult). After adult emergence, the lady beetles from the same prey densities were allowed to mate and then were transferred to individual experimental arenas as described earlier. The dishes contained the same prey densities that the beetles had been fed in their immature stages. The mortality and number of eggs laid were recorded daily until all adults died. The number of replicates was between 32 and 38 for both larval and adult stages at each prey density.

2.4. Data Analysis. The life history data of all individuals of $H$. variegata were analyzed according to an age-stage, two-sex life table $[29,30]$. The program TWO-SEX-MSChart [34] designed in visual BASIC for the Windows operation system was used to analyze the data and population parameters. It is available at http://140.120.197.173/Ecology/ prod02.htm (Chung Hsing University) and http://nhsbig.inhs .uiuc.edu/wes/chi.html (Illinois Natural History Survey).

The age-stage-specific survival rate $\left(s_{x j}\right)$ (where $x=$ age and $j=$ stage), the age-stage-specific fecundity $\left(f_{x j}\right)$, the age-specific survival rate $\left(l_{x}\right)$, the age-specific fecundity $\left(m_{x}\right)$, and the population parameters $\left(r_{m}\right.$, the intrinsic rate of increase; $\lambda$, the finite rate of increase, $\lambda=e^{r} ; R_{0}$, the net reproductive rate; $T$, the mean generation time) were calculated accordingly. In the age-stage, two-sex life table, the $l_{x}$ and $m_{x}$ were calculated as

$$
\begin{gathered}
l_{x}=\sum_{j=1}^{k} s_{x j}, \\
m_{x}=\frac{\sum_{j=1}^{k} s_{x j} f_{x j}}{\sum_{j=1}^{\beta} s_{x j}},
\end{gathered}
$$

where $k$ is the number of stages [29]. In this paper, the intrinsic rate of increase was calculated using the iterative bisection method from

$$
\sum_{x=0}^{\infty} e^{-r(x+1)} l_{x} m_{x}=1,
$$

with age indexed from 0 [35]. The mean generation time is the time length that a population needs to increase to $R_{0}$ times of its size as the stable age distribution and the stable increase rate are reached, that is, $e^{r t}=R_{0}$ or $\lambda^{T}=R_{0}$. Thus, it is calculated as $T=\ln R_{0} / r$. The gross reproductive rate (GRR) is calculated as GRR $=\sum m_{x}$.

The standard errors of the life table parameters were estimated by the Jackknife technique $[36,37]$. We used the Duncan and LSD procedures [38] to compare the differences among treatments following the description of Sokal and Rohlf [37]. 
TABLE 1: Developmental time, longevity, and fecundity of Hippodamia variegata females reared on different densities of Aphis gossypii (all data \pm SE).

\begin{tabular}{lcccccc}
\hline Prey density & Preadult period & APOP & TPOP & $\begin{array}{c}\text { Oviposition } \\
\text { period (day) }\end{array}$ & $\begin{array}{c}\text { Fecundity } \\
(\text { eggs/female) }\end{array}$ & $\begin{array}{c}\text { Female longevity } \\
(\text { day })\end{array}$ \\
\hline 20 & $16.49 \pm 0.29^{\mathrm{a}}$ & $13.19 \pm 1.78^{\mathrm{a}}$ & $29.9 \pm 1.91^{\mathrm{a}}$ & $11.95 \pm 1.41^{\mathrm{a}}$ & $70.7 \pm 8.3^{\mathrm{a}}$ & $81.78 \pm 8.03^{\mathrm{a}}$ \\
40 & $14.24 \pm 0.13^{\mathrm{b}}$ & $11.67 \pm 0.90^{\mathrm{d}}$ & $25.33 \pm 0.87^{\mathrm{b}}$ & $47.11 \pm 2.65^{\mathrm{b}}$ & $404.2 \pm 44.4^{\mathrm{b}}$ & $84.83 \pm 2.95^{\mathrm{a}}$ \\
60 & $13.97 \pm 0.06^{\mathrm{bc}}$ & $8 \pm 0.57^{\mathrm{bc}}$ & $22.07 \pm 0.58^{\mathrm{b}}$ & $58.8 \pm 23.91^{\mathrm{b}}$ & $787.7 \pm 23.9^{\mathrm{c}}$ & $86.33 \pm 2.36^{\mathrm{a}}$ \\
80 & $13.71 \pm 0.07^{\mathrm{bc}}$ & $7.31 \pm 1.46^{\mathrm{b}}$ & $21 \pm 1.50^{\mathrm{b}}$ & $59 \pm 57.64^{\mathrm{c}}$ & $1319.8 \pm 45.2^{\mathrm{d}}$ & $87.73 \pm 2.09^{\mathrm{a}}$ \\
100 & $13.65 \pm 0.09^{\mathrm{c}}$ & $5.67 \pm 1.19^{\mathrm{dc}}$ & $19.89 \pm 1.19^{\mathrm{b}}$ & $64.62 \pm 2.45^{\mathrm{c}}$ & $1332.2 \pm 57.6^{\mathrm{d}}$ & $94.31 \pm 2.04^{\mathrm{b}}$ \\
\hline
\end{tabular}

APOP: adult preovipositional period; TPOP: total preovipositional period (from egg to first oviposition). Within columns, values followed by the same letter do not differ significantly $(P<0.0001)$ using the Duncan-LSD procedure.

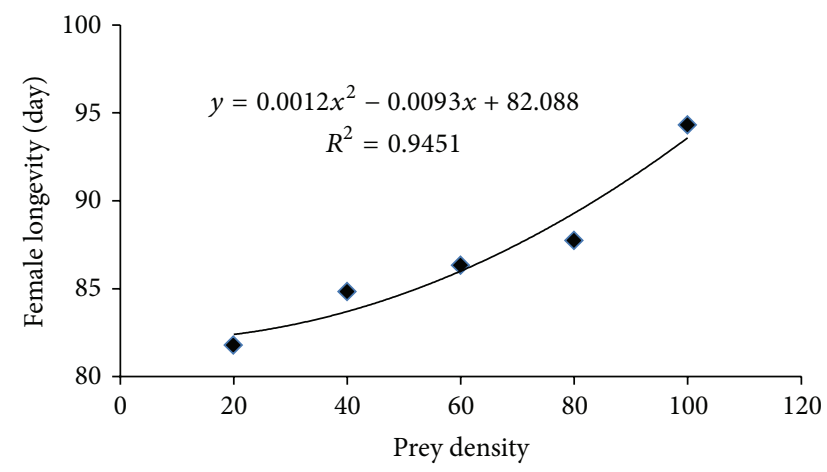

Figure 1: Density-dependent longevity of female Hippodamia variegata fed on different densities of third instar nymphs of Aphis gossypii.

\section{Results}

Developmental time of $H$. variegata was affected by prey densities. The total developmental time (from first instar larva to adult) decreased with increasing prey density, up to 100 preys/day $(F=280.67 ; \mathrm{df}=5,188 ; P<0.0001)$. The shortest developmental time was obtained at a prey density of 100 aphids/day, and the longest was at a prey density of 20 aphids/day (Table 1). The adult preovipositional periods (APOP), that is, the duration from adult emergence to first oviposition, was also significantly shorter in females fed on 100 preys per day than those fed as larva and adults on lower prey densities $(F=10.75 ; \mathrm{df}=4,84 ; P<0.0001)$.

The total preovipositional period (TPOP), that is, the duration from egg to first oviposition, was longer at 20 prey per day, and no noticeable change was observed at higher prey densities $(F=15.55 ; \mathrm{df}=4,84 ; P<0.0001)$. The densities of 40 and 60 prey per day provided to immature stages and adult predators led to significantly longer oviposition periods than those fed on 20 preys per day. Females fed on 80 and 100 preys per day had also significantly longer oviposition periods than those fed on lower prey densities $(F=25.92$; $\mathrm{df}=$ $4,84 ; P<0.0001)$. The prey densities provided to immature stages and adults had significant effect on female longevity. It was increased as prey density increased (Figure 1). The female fecundity was found to be significantly prey density dependent $(F=29.365 ; \mathrm{df}=1,3 ; P=0.050)$ (Figure 2$)$. Those females fed on 20 preys per day had significantly lower

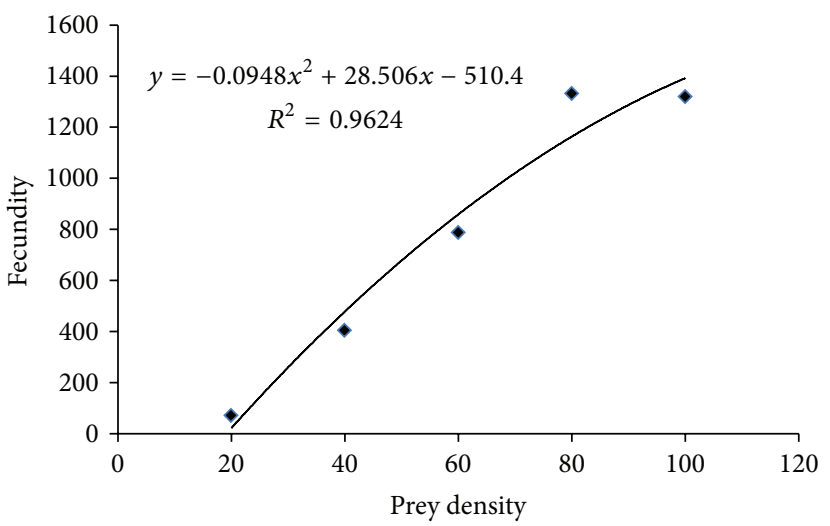

FIGURE 2: Relationship between fecundity of Hippodamia variegata and different densities of third instar nymphs of Aphis gossypii.

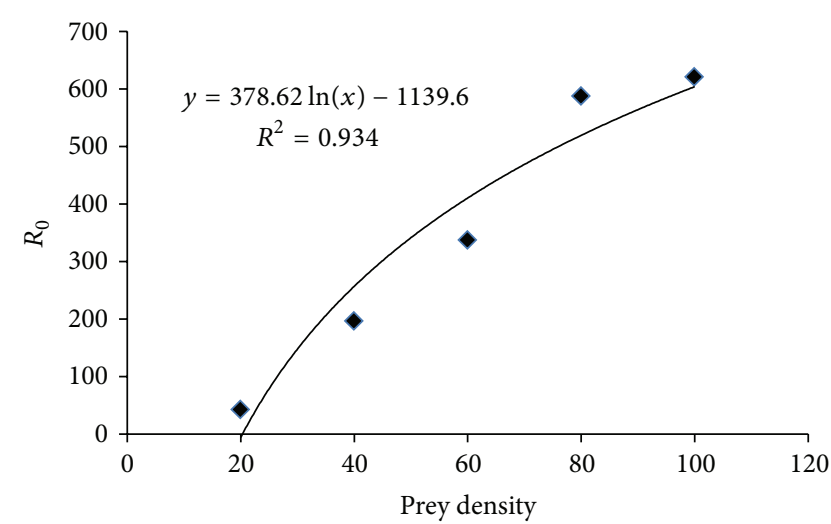

FIgURE 3: Density-dependent net reproductive rate $\left(R_{0}\right)$ of Hippodamia variegata fed on different densities of third instar nymphs of Aphis gossypii.

fecundity than those fed on 40 preys per day. Females fed on 80 and 100 preys per day had significantly higher fecundity than those fed on 60 preys per day $(F=37.22$; df $=4,84$; $P<0.0001)$ (Table 1$)$. The net reproduction rate $\left(R_{0}\right)(F=$ 9.99; df $=4,177 ; P<0.0001)$ increased significantly with increasing prey densities per day $(F=34.267$; $\mathrm{df}=1,3$; $P=0.029)$ (Figure 3 ). The gross reproductive rates (GRR) $(F=8.06 ; \mathrm{df}=4,177 ; P<0.0001)$ were also found to be significantly prey density dependent $(F=21.094$; $\mathrm{df}=1,3$; 
TABLE 2: The population parameters: intrinsic rate of increase $\left(\mathrm{d}^{-1}\right)$, finite rate of increase $\left(\mathrm{d}^{-1}\right)$, net reproductive rate (offspring/individual), mean generation time (day), and gross reproductive rate (offspring/individual) of Hippodamia variegata reared on different densities of Aphis gossypii.

\begin{tabular}{lccccc}
\hline Prey density & $\begin{array}{c}\text { Intrinsic rate of } \\
\text { increase }\left(r_{m}\right)\end{array}$ & $\begin{array}{c}\text { Finite rate of } \\
\text { increase }(\lambda)\end{array}$ & $\begin{array}{c}\text { Net reproductive } \\
\text { rate }\left(R_{0}\right)\end{array}$ & $\begin{array}{c}\text { Mean generation } \\
\text { time }(T)\end{array}$ & $\begin{array}{c}\text { Gross reproductive } \\
\text { rate }(\mathrm{GRR})\end{array}$ \\
\hline 20 & $0.0788 \pm 0.005^{\mathrm{c}}$ & $1.0821 \pm 0.005^{\mathrm{c}}$ & $42.76 \pm 7.55^{\mathrm{c}}$ & $47.6 \pm 1.86^{\mathrm{a}}$ & $85.34 \pm 12.64^{\mathrm{a}}$ \\
40 & $0.14618 \pm 0.007^{\mathrm{b}}$ & $1.1574 \pm 0.009^{\mathrm{b}}$ & $196.62 \pm 39.8^{\mathrm{bc}}$ & $37.74 \pm 2.83^{\mathrm{b}}$ & $229.64 \pm 40.25^{\mathrm{a}}$ \\
60 & $0.1551 \pm 0.009^{\mathrm{b}}$ & $1.1678 \pm 0.010^{\mathrm{b}}$ & $337.57 \pm 67.6^{\mathrm{b}}$ & $37.52 \pm 1.43^{\mathrm{b}}$ & $528.23 \pm 144.2^{\mathrm{b}}$ \\
80 & $0.1689 \pm 0.013^{\mathrm{ab}}$ & $1.1841 \pm 0.016^{\mathrm{ab}}$ & $587.74 \pm 117.82^{\mathrm{a}}$ & $36.13 \pm 1.26^{\mathrm{b}}$ & $700.87 \pm 119.19^{\mathrm{b}}$ \\
100 & $0.18700 \pm 0.009^{\mathrm{a}}$ & $1.2056 \pm 0.011^{\mathrm{a}}$ & $621.09 \pm 116.56^{\mathrm{a}}$ & $34.39 \pm 1.26^{\mathrm{b}}$ & $641.52 \pm 116.4^{\mathrm{b}}$ \\
\hline
\end{tabular}

Within columns, values followed by the same letter do not differ significantly $(P<0.0001)$ using the Duncan-LSD procedure.

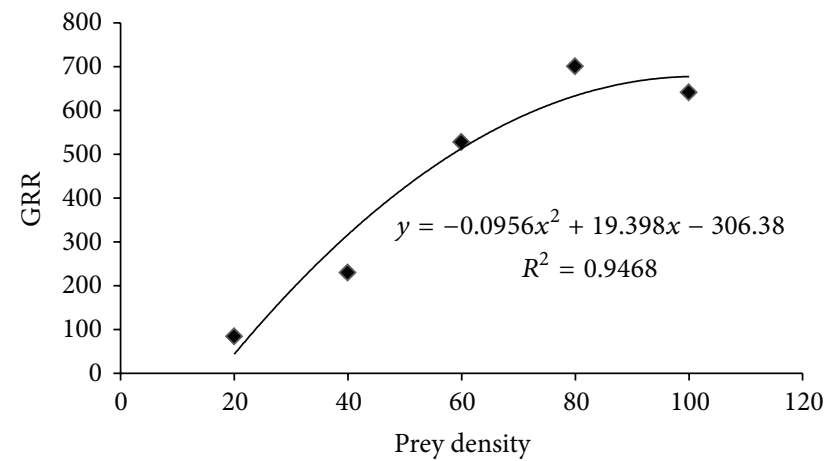

FIgURE 4: Relationship between gross reproductive rate of Hippodamia variegata and different densities of third instar nymphs of Aphis gossypii.

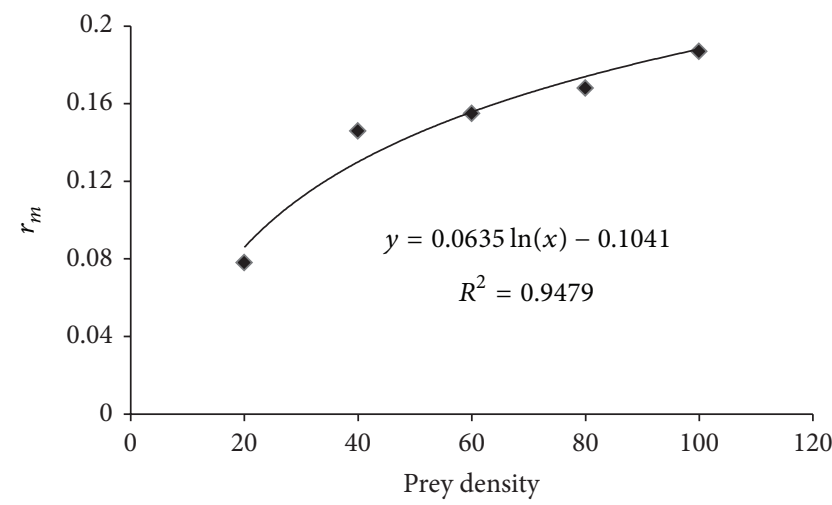

FIGURE 5: Density-dependent $r_{m}$ of Hippodamia variegata fed on different densities of third instar nymphs of Aphis gossypii.

$P=0.019)$ (Figure 4$)$. The finite rate of increase $(\lambda)(F=$ 18.78; $\mathrm{df}=4,177 ; P<0.0001)$ showed an increase as prey densities increased. The intrinsic rate of increase $\left(r_{m}\right)(F=$ 19.96; $\mathrm{df}=4,177 ; P<0.0001)$ showed a decelerating rate of increase as prey densities increased. It was also significantly density dependent $(F=15.896 ; \mathrm{df}=1,3 ; P=0.028)$ (Figure 5). Increasing prey density resulted in shorter mean generation time $(T)$, as it was longer at 20 prey per day and no noticeable change was observed at higher prey densities $(F=$ 8.53; df $=4,177 ; P<0.0001$ ) (Table 2). The life expectancy of a newly emerged female and male ladybeetles ranged from
84 to 97 and 69 to 80.4 days at different prey densities, respectively. The reproductive value $(v x j)$ is the contribution of individuals of age $x$ and stage $j$ to the future population (Figure 6). However, the peak reproductive value appeared at ages of 49 day on 20 prey/day, 67 day on 40 prey/day, 45 day on 60 prey/day, 39 day on 80 prey/day, and 37 day on 100 prey/day. This showed that female lady beetles at ages of 37, $39,45,49$ and 67 days made the highest contribution to the population when reared on 100, 80, (60 and 20), and 40 prey densities per day, respectively. The peak reproductive value was also shown to be prey density dependent $(F=15.715$; $\mathrm{df}=1,3 ; P=0.029$ ) (Figure 7 ).

\section{Discussion}

Statistically significant differences were obtained in the biological and life table parameters of $H$. variegata at varying densities of third instar nymphs of A. gossypii. The preovipositional periods and the total preovipositional period of the female predator were reduced with increasing prey density. Yaşar and Ozger [39] also observed that increasing Hyalopterus pruni density as prey resulted in shorter preovipositional and total pre-ovipositional periods in Adalia fasciatopunctata revelierei (Mulsant). Atlihan and Güldal [40] also obtained similar results in the study of S. subvillosus (Goeze) fed on Hyalopterus pruni (Geoffroy). The oviposition period increased as prey density increased. Feeding on different prey densities had significant effects on the longevity and reproduction of $H$. variegata, as increasing prey density increased these parameters directly. Studies on the effect of prey density on the longevity and fecundity of other predators are also in agreement with our findings [39-41]. Longevity was not significantly different up to 80 preys per day, but there was a significant difference among 80 preys/day and the other prey density levels. The lowest fecundity was observed at 20 prey/day, but a rapid increase was found at higher density levels with no significant difference between 80 and 100 preys per day. According to these results, it can be concluded that an increase in prey density will result in longer longevity which in turn will lead to a directly density-dependent reproduction rate.

It was revealed that at higher prey densities, the peak reproductive value would occur at earlier ages of the female predator. This is most probably due to the amount of biomass 

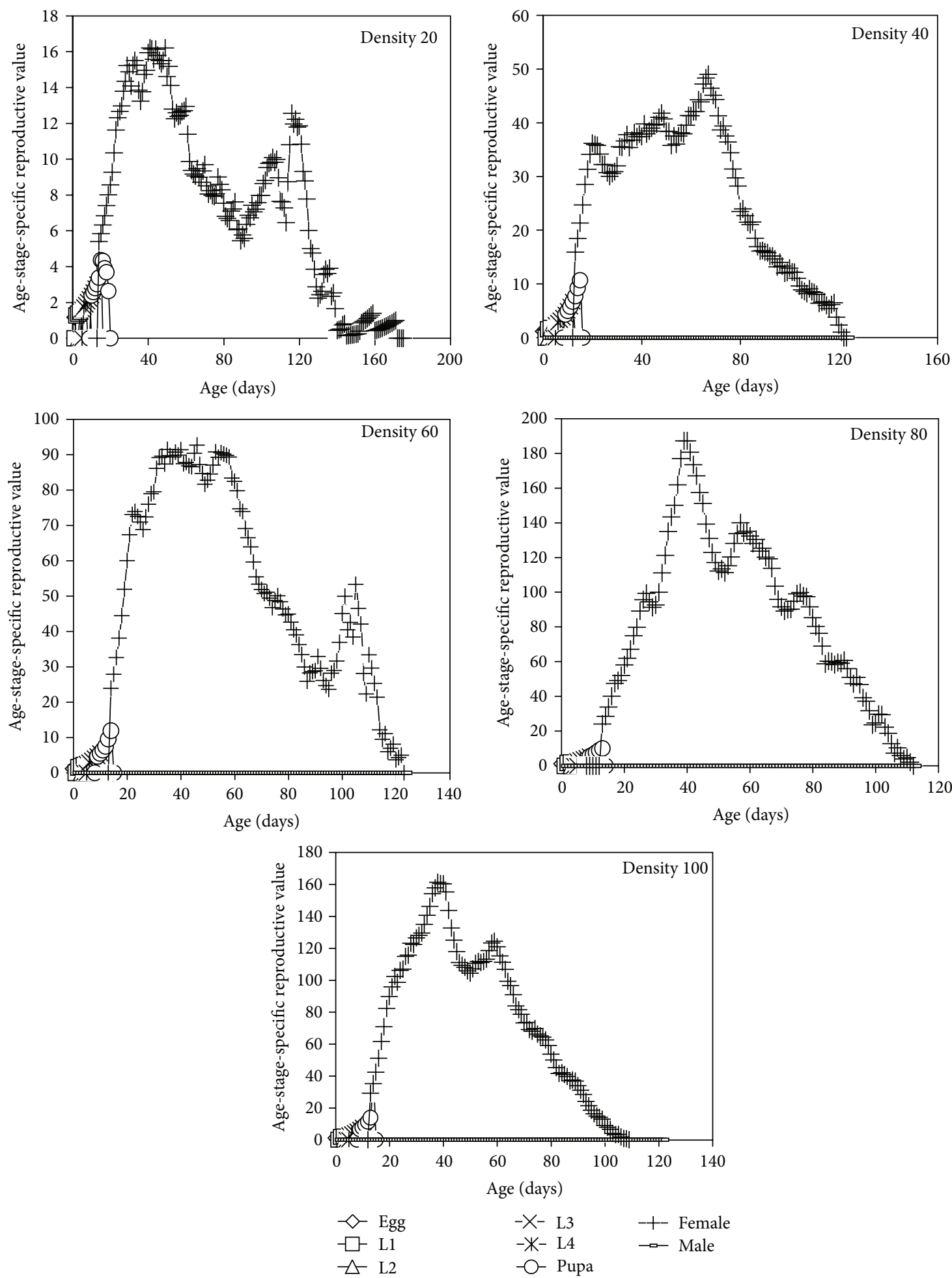

Figure 6: Age-stage-specific reproductive value of Hippodamia variegata fed on 20, 40, 60, 80, and 100 of Aphis gossypii at $25 \pm 1^{\circ} \mathrm{C}, 70 \% \pm 5 \%$ relative humidity, photoperiod $16: 8 \mathrm{~h}(\mathrm{~L}: \mathrm{D})$.

that an individual female obtains at higher prey availability. A prey density dependency was found in the peak reproductive value of female $H$. variegata. Research workers have also found some other kinds of relationships among life table parameters as Yu et al. [31] proved a relationship among gross reproduction rate, net reproduction rate, and preadult survivorship of Lemnia biplagiata (Col.: Coccinellidae) feeding on A. gossypii. 


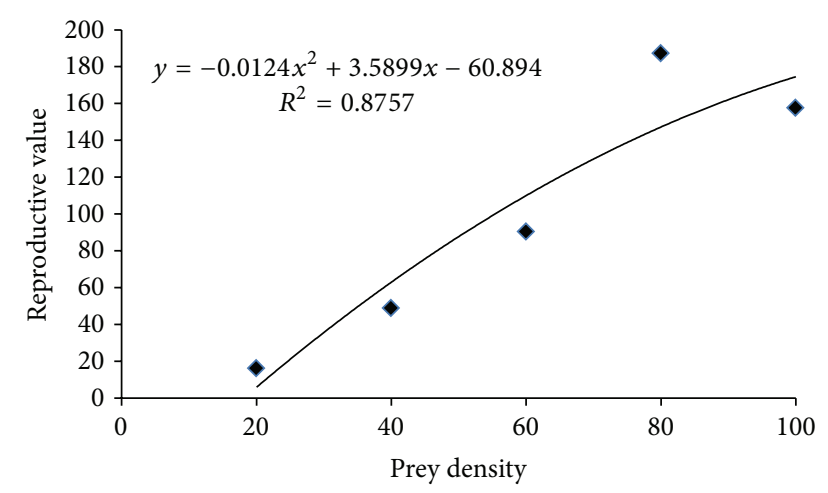

FIgURE 7: Peak reproductive value of Hippodamia variegata depending on different densities of third instar nymphs of Aphis gossypii.

The intrinsic rate of increase $(r)$, the finite rate of increase $(\lambda)$, the net reproduction rate $\left(R_{0}\right)$, and the gross reproductive rates (GRR) also showed some kinds of direct prey density dependency. Atlihan and Güldal [40] obtained similar trends in demographic parameters of $S$. subvillosus (Goeze) fed on different densities of Hyalopterus pruni.

Based on the results obtained by us, the lady beetle, $H$. variegate, can be considered as an effective biocontrol agent of A. gossypii, as it developed successfully to adult stage at all prey densities and reproduced even at lower prey densities. However, it is obvious that higher prey densities are more suitable than lower ones to rear this predator and increase its population. According to the results, it can be also concluded that $H$. variegata is a useful natural enemy in the population dynamics of its preys, especially A. gossypii. This study could result in the development of management tactics to control aphid pests, as this kind of laboratory studies provide better insights into the management development and population dynamics of insects.

\section{Acknowledgment}

The authors thank the authorities of the Faculty of Agriculture, University of Guilan, for providing them with research facilities and for their financial support.

\section{References}

[1] E. H. Nelson and J. A. Rosenheim, "Encounters between aphids and their predators: the relative frequencies of disturbance and consumption," Entomologia Experimentalis et Applicata, vol. 118, no. 3, pp. 211-219, 2006.

[2] J. S. Kennedy, M. F. Day, and V. F. Eastop, A Conspectus of Aphids as Vectors of Plant Viruses, Commonwealth Institute of Entomology, London, UK, 1962.

[3] F. Raboudi, A. Ben Moussa, H. Makni, M. Marrakchi, and M. Makni, "Seriological detection of plant viruses in their aphid vectors and host plants in Tunisia," EPPO Bulletin, vol. 32, no. 3, pp. 495-498, 2002.

[4] F. Leclant and J. P. Deguine, "Aphids (Hemiptera: Aphididae)," in Insect Pests of Cotton, G. A. Matthew and J. P. Tunstall, Eds., pp. 285-323, CAB International, Wallingford, UK, 1994.
[5] W. E. Snyder, S. N. Ballard, S. Yang et al., "Complementary biocontrol of aphids by the ladybird beetle Harmonia axyridis and the parasitoid Aphelinus asychis on greenhouse roses," Biological Control, vol. 30, no. 2, pp. 229-235, 2004.

[6] B. K. Agarwala and A. F. G. Dixon, "Laboratory study of cannibalism and interspecific predation in ladybirds," Ecological Entomology, vol. 17, no. 4, pp. 303-309, 1992.

[7] J. J. Obrycki and C. J. Orr, "Suitability of three prey species for Nearctic populations of Coccinella septempunctata, Hippodamia variegata, and Propylea quatuordecimpunctata (Coleoptera: Coccinellidae)," Journal of Economic Entomology, vol. 83, no. 4, pp. 1292-1297, 1990.

[8] E. A. El-Hag and A. A. Zaitoon, "Biological parameters for four Coccinellid species in central Saudi Arabia," Biological Control, vol. 7, no. 3, pp. 316-319, 1996.

[9] G. F. González, "Lista actualizada de espcies de Coccinelldae (Insecta: Coleoptea) presents en Chile," 2012 http://www .coccinellidae.cl/.

[10] I. Hodek and A. Honek, Ecology of Coccinellidae, Kluwer Academic, Dordrecht, The Netherlands, 1996.

[11] B. A. Franzmann, "Hippodamia variegata (Goeze) (Coleoptera: Coccinellidae), a predacious ladybird new in Australia," Australian Journal of Entomology, vol. 41, no. 4, pp. 375-377, 2002.

[12] J. C. Legaspi, "Life history of Podisus maculiventris (Heteroptera: Pentatomidae) adult females under different constant temperatures," Environmental Entomology, vol. 33, no. 5, pp. 1200-1206, 2004.

[13] T. R. E. Southwood, Ecological Methods with Particular Reference to the Study of Insect Populations, Methuen, London, UK, 1966.

[14] J. R. Carey, "Insect biodemography," Annual Review of Entomology, vol. 46, pp. 79-110, 2001.

[15] H. Chi and T. Yang, "Two-sex life table and predation rate of Propylaea japonica Thunberg (Coleoptera: Coccinellidae) fed on Myzus persicae (Sulzer) (Homoptera: Aphididae)," Environmental Entomology, vol. 32, no. 2, pp. 327-333, 2003.

[16] A. Janssen and M. W. Sabelis, "Phytoseiid life-histories, local predator-prey dynamics, and strategies for control of tetranychid mites," Experimental and Applied Acarology, vol. 14, no. 3-4, pp. 233-250, 1992.

[17] D. L. Hansen, H. F. Brødsgaard, and A. Enkegaard, "Life table characteristics of Macrolophus caliginosus preying upon Tetranychus urticae," Entomologia Experimentalis et Applicata, vol. 93, no. 3, pp. 269-275, 1999.

[18] J. Havelka and R. Zemek, "Life table parameters and oviposition dynamics of various populations of the predacious gall-midge Aphidoletes aphidimyza," Entomologia Experimentalis et Applicata, vol. 91, no. 3, pp. 481-484, 1999.

[19] S. X. Ren, P. A. Stansly, and T. X. Liu, "Life history of the whitefly predator Nephaspis oculatus (Coleoptera: Coccinellidae) at six constant temperatures," Biological Control, vol. 23, no. 3, pp. 262-268, 2002.

[20] A. Russo, G. E. Cocuzza, and M. C. Vasta, "Life tables of Xylocoris flavipes (Hemiptera: Anthocoridae) feeding on Tribolium castaneum (Coleoptera: Tenebrionidae)," Journal of Stored Products Research, vol. 40, no. 1, pp. 103-112, 2004.

[21] J. C. Zanuncio, W. P. Lemos, M. C. Lacerda, T. V. Zanuncio, J. E. Serrão, and E. Bauce, "Age-dependent fecundity and fertility life tables of the predator Brontocoris tabidus (Heteroptera: Pentatomidae) under field conditions," Journal of Economic Entomology, vol. 99, no. 2, pp. 401-407, 2006. 
[22] E. G. Lewis, "On the generation and growth of a population," Sankhya, vol. 6, pp. 93-96, 1942.

[23] P. H. Leslie, "On the use of matrices in certain population mathematics," Biometrika, vol. 33, no. 3, pp. 183-212, 1945.

[24] L. Birch, "The intrinsic rate of natural increase in an insect population," Journal of Animal Ecology, vol. 17, no. 1, pp. 15-26, 1948.

[25] M. El Habi, A. Sekkat, L. El Jadd, and A. Boumezzough, "Biology of Hippodamia variegata (Col., Coccinellidae) and its suitability against Aphis gossypii Glov (Hom., Aphididae) on cucumber under greenhouse conditions," Journal of Applied Entomology, vol. 124, no. 9-10, pp. 365-374, 2000.

[26] A. Lanzoni, G. Accinelli, G. G. Bazzocchi, and G. Burgio, "Biological traits and life table of the exotic Harmonia axyridis compared with Hippodamia variegata, and Adalia bipunctata (Col., Coccinellidae)," Journal of Applied Entomology, vol. 128, no. 4, pp. 298-306, 2004.

[27] M. Mollashahi, A. Sahragard, and R. Hossaini, "Determination of life table parameters of lady beetle, Hippodamia variegata (Col: Coccinellidae) under laboratory conditions," Journal of Agricultural Sciences, vol. 1, pp. 47-60, 2004.

[28] D. C. Kontodimas and G. J. Stathas, "Phenology, fecundity and life table parameters of the predator Hippodamia variegata reared on Dysaphis crataegi," BioControl, vol. 50, no. 2, pp. 223233, 2005

[29] H. Chi and H. Liu, "Two new methods for the study of insect population ecology," Bulletin of the Institute of Zoology, Academia of Sinica, vol. 24, pp. 225-240, 1985.

[30] H. Chi, "Life-table analysis incorporating both sexes and variable development rates among individuals," Environmental Entomology, vol. 17, no. 1, pp. 26-34, 1988.

[31] J. Z. Yu, H. Chi, and B. H. Chen, "Life table and predation of Lemnia biplagiata (Coleoptera: Coccinellidae) fed on Aphis gossypii (Homoptera: Aphididae) with a proof on relationship among gross reproduction rate, net reproduction rate, and preadult survivorship," Annals of the Entomological Society of America, vol. 98, no. 4, pp. 475-482, 2005.

[32] M. I. Schneider, N. Sanchez, S. Pineda, H. Chi, and A. Ronco, "Impact of glyphosate on the development, fertility and demography of Chrysoperla externa (Neuroptera: Chrysopidae): ecological approach," Chemosphere, vol. 76, no. 10, pp. 1451-1455, 2009.

[33] H. Chi and H. Su, "Age-stage, two-sex life tables of Aphidius gifuensis (Ashmead) (Hymenoptera: Braconidae) and its host Myzus persicae (Sulzer) (Homoptera: Aphididae) with mathematical proof of the relationship between female fecundity and the net reproductive rate," Environmental Entomology, vol. 35, no. 1, pp. 10-21, 2006.

[34] H. Chi, TWOSEX-MSChart: Computer Program for Age-Stage, Two-Sex Life Table Analysis, National Chung Hsing University, Taichung, Taiwan, 2005.

[35] D. Goodman, "Optimal life histories, optimal notation and the value of reproductive value," American Naturalist, vol. 119, no. 6, pp. 803-823, 1982.

[36] J. S. Meyer, C. G. Ingersoll, L. L. McDonald, and M. S. Boyce, "Estimating uncertainty in population growth rates: jackknife vs. bootstrap techniques," Ecology, vol. 67, no. 5, pp. 1156-1166, 1986.

[37] R. R. Sokal and F. J. Rohlf, Biometry: The Principles and Practice of Statistics in Biological Research, W. H. Freeman and Co., New York, NY, USA, 4th edition, 2012.
[38] C. W. Dunnett, "Pairwise multiple comparisons in the unequal variance case," Journal of the American Statistical Association, vol. 75, no. 372, pp. 796-800, 1980.

[39] B. Yaşar and S. Ozger, "Development, feeding and reproduction responses of Adalia fasciatopunctata (Mulsant) (Coleoptera: Coccinellidae) to Hyalopterus pruni (Geoffroy) (Homoptera: Aphididae)," Journal of Pest Science, vol. 78, no. 4, pp. 199-203, 2005.

[40] R. Atlihan and H. Güldal, "Prey density-dependent feeding activity and life history of Scymnus subvillosus," Phytoparasitica, vol. 37, no. 1, pp. 35-41, 2009.

[41] B. K. Agarwala, H. Yasuda, and S. Sato, "Life history response of a predatory ladybird, Harmonia axyridis (Pallas) (Coleoptera: Coccinellidae), to food stress," Applied Entomology and Zoology, vol. 43, no. 2, pp. 183-189, 2008. 

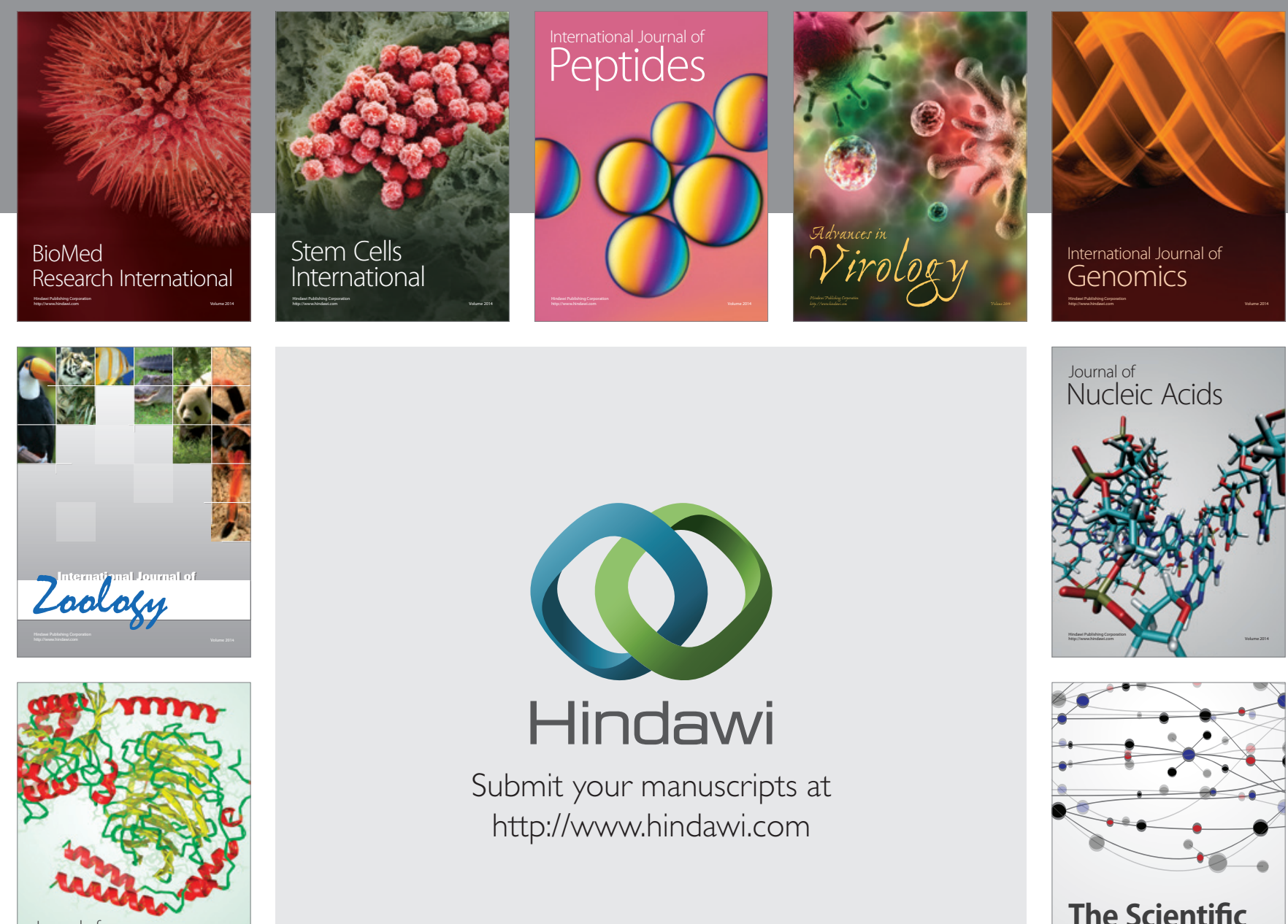

Submit your manuscripts at

http://www.hindawi.com

Journal of
Signal Transduction
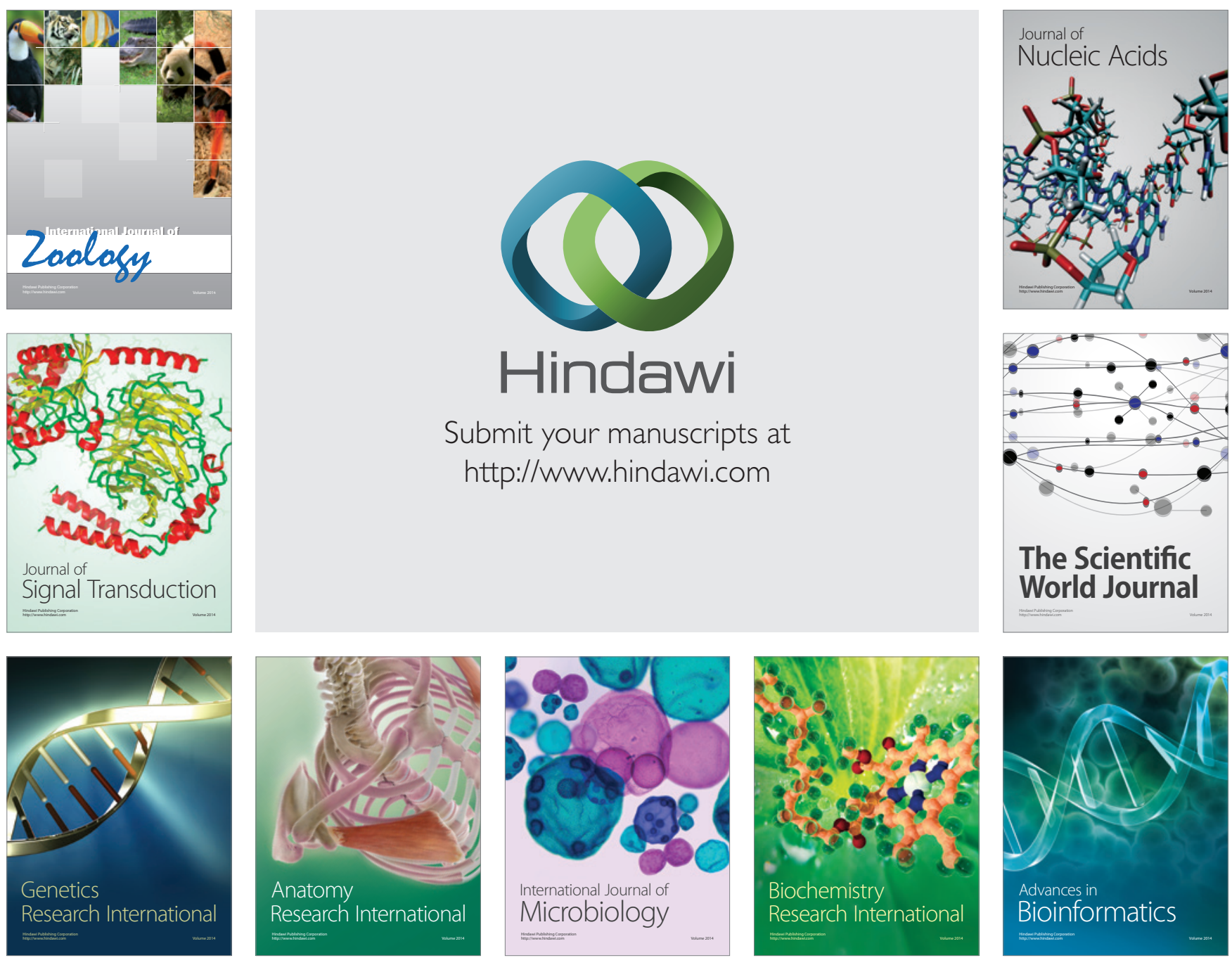

The Scientific World Journal
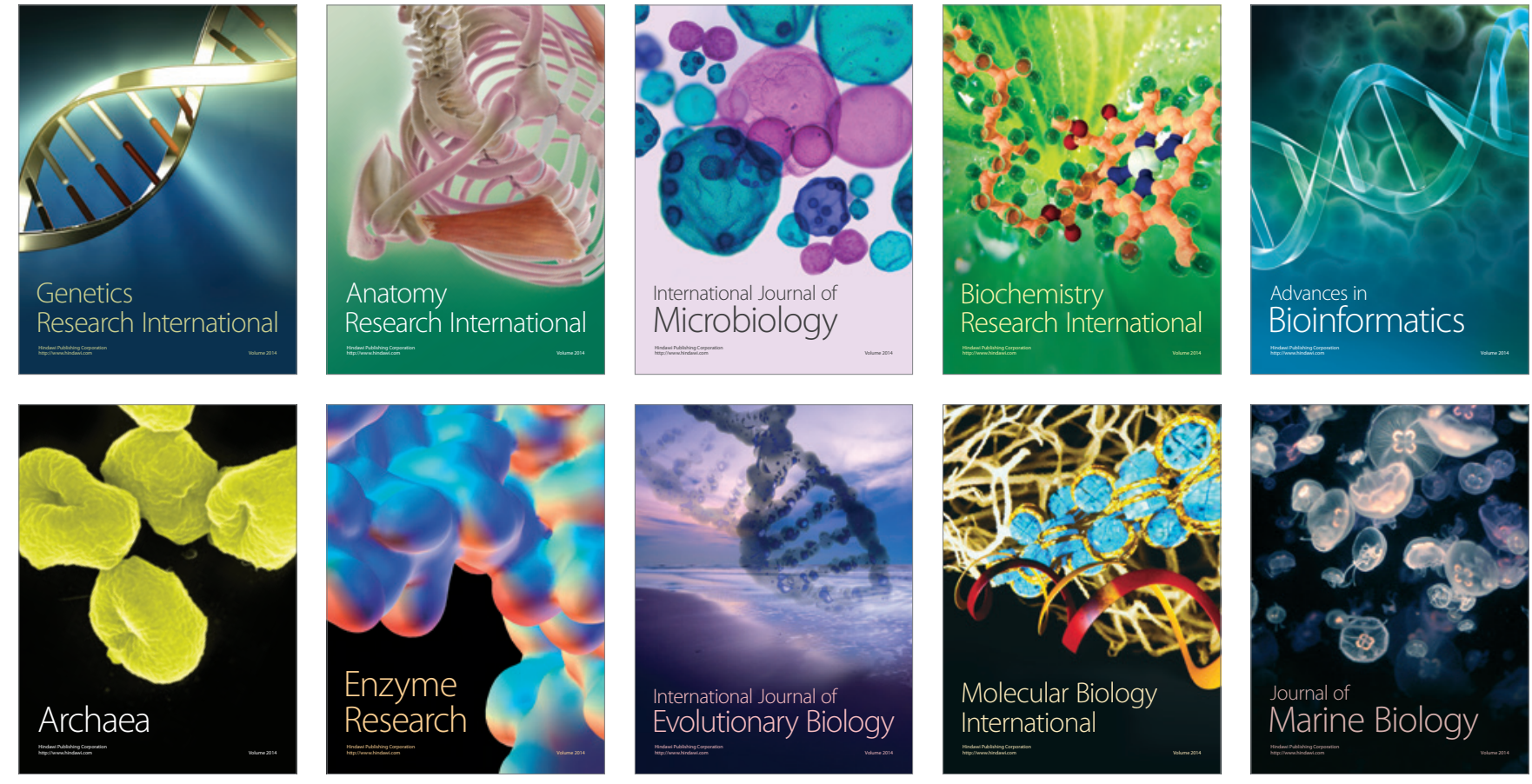